Die

\title{
Cholera in Syrien
}

und

\author{
die Choleraprophylaxe in Europa.
}

Von

Max von Pettenkofer.

Separatabdruck aus Band XII. der Zeitschrift für Biologie.

München 1876.

Druck und Verlag von R. Oldenbourg. 
